\title{
Citrus Rootstocks and Their On-Site Evaluation ${ }^{1}$
}

William S. Castle and James J. Ferguson ${ }^{2}$

\section{Rootstock Planting}

What rootstock to plant? That's an ever-present and always challenging question. In conversations with growers, this question is asked frequently because of problems with Swingle citrumelo, continued loss of trees on sour orange, and low solids for grapefruit grown on Smooth Flat Seville.

The commercial rootstock situation has actually changed very little, so growers are faced with essentially the same choices now as five or ten years ago. However, it seems that the old choices are less attractive partially because more demanding requirements have been placed on this same pool of rootstocks. For example, a grower called recently requesting advice on rootstocks for Valencia to be grown for juice and planted on Riviera soil. The existing grove consisted of 60 -foot beds. The cost of land leveling and rebedding was too high so the original beds were going to be left in place with rows 30 feet apart. With this scenario, the grower reasonably desired a highly productive, large tree with excellent quality fruit. It was easy to list the choices and agree why they were not acceptable: Swingle and Carrizo - concerns about tree size and longevity on Riviera soil; Cleo - concerns about low yield and root and foot rot; rough lemon and
Volkamer lemon - good tree size and high yields but poor juice quality even with Valencia; and sour orange which is not generally considered a choice because of tristeza susceptibility. The outcome was that the grower selected several rootstocks, including Sun Chu Sha and x639, that are not as well known throughout the industry.

Another recent conversation was about poorly performing Rohde Red Valencia on Swingle growing in Immokalee fine sand soil. The grower wished to consider different rootstocks for a new planting. Any attempt to assess this situation was hampered by several realities. First, maybe the rootstock was not the major issue because the trees had not been propagated with the best budline selection of Rohde Red Valencia. Second, maybe the rootstock was the issue because the site was not suited to Swingle. Third, maybe too little is known about the optimum cultural practices for trees on Swingle. Keeping in mind that there are many places where Rohde Red Valencia trees on Swingle grow just fine, these observations suggest that one of the more serious wrinkles in making rootstock decisions is that literally every situation is different in some respect and is site specific. Generalizations are useful but can sometimes lead to wrong decisions. In this instance, the best approach may be to gather details

1. This document is HS, one of a series of the Horticultural Sciences Department, Florida Cooperative Extension Service, Institute of Food and Agricultural Sciences, University of Florida. Publication date: August 2003. Please visit the EDIS Web site at http://edis.ifas.ufl.edu.

2. William S. Castle, professor, CREC-Lake Alfred, James J. Ferguson, professor, Horticultural Sciences Department, Cooperative Extension Service, Institute of Food and Agricultural Sciences, University of Florida, Gainesville, 32611.

The Institute of Food and Agricultural Sciences is an equal opportunity/affirmative action employer authorized to provide research, educational information and other services only to individuals and institutions that function without regard to race, color, sex, age, handicap, or national origin. For information on obtaining other extension publications, contact your county Cooperative Extension Service office. Florida Cooperative Extension Service/Institute of Food and Agricultural Sciences/University of Florida/Christine Taylor Waddill, Dean. 
about the site, consider Swingle or Carrizo as the best choices, and if not, then begin consideration of other choices (see also Considerations for Choosing the Right Rootstocks at http://edis.ifas.ufl.edu/HS178). In this specific situation, Immokalee fine sand probably does not preclude the use of Swingle because there is too much evidence to the contrary. Nevertheless, some on-site evaluation is clearly justified. As more is learned about rootstocks and soil, it may be determined that the match between Swingle and Immokalee fine sand may not be the best one.

A final example relates to those places where grapefruit trees on sour orange have been the long time favorite. Those trees were common in the Indian River region on soils such as Riviera, Pineda, and Wabasso as well as on Winder and Chobee soils that are now generally considered marginal for Swingle citrumelo. Smooth Flat Seville became an unusually popular rootstock in the Indian River for grapefruit and has been the preferred sour orange replacement over Swingle. Choosing Smooth Flat Seville often has been made with expectations for similar performance and soil adaptability to sour orange. The latter seems to be proving true, but the former has been called into question lately with some grapefruit never meeting minimum maturity standards during a season.

Conversations with Indian River growers are often about these old sour orange sites where either the original trees on sour orange are being pushed out, or declining replacement trees on Swingle are now being removed. What are the rootstock choices when it is difficult to let go of the traditional expectations like good yield, excellent external and internal quality fruit, and long life? The answer has to be based on site knowledge and willingness to try new rootstocks. It is tempting to suggest that no consideration be given to any trifoliate orange hybrid like Swingle or Carrizo, but that would be unwise until more is learned about other choices such as those described below. Meanwhile, there are other options. Rootstocks interact with their site-specific environment. For this reason, the use of Swingle in Riviera soil might be acceptable if the depth to clay is greater than about 30 inches, and bed construction was designed to conserve the surface or " $\mathrm{A}$ horizon" that contains organic matter (see also Some Practical Matters Related to Riviera Soil, Depth to Clay, Water Table, Soil Organic Matter, and Swingle Citrumelo Root Systems at http://edis.ifas.ufl.edu/HS146).

The field situation in our industry today demonstrates how easily changing circumstances and knowledge can shift emphasis on individual rootstock traits. Swingle citrumelo has been an excellent choice. It has some deficiencies that have largely transferred earlier concerns about fruit, storage, and shipping quality to questions about whether to use the rootstock at all because of soil and site factors affecting tree longevity. Cleo has always been a rootstock of modest interest to citrus growers, but now its ability to survive where trees on Swingle decline has sparked new interest. The changing environment has also focused attention on the difficulty the IFAS and USDA plant improvement team has in meeting current demands for new rootstocks. New rootstocks are being produced routinely, but the evaluation time needs to be reduced through grower partnerships. This means on-farm evaluations, and the following are some candidates.

\section{Rootstocks for Grower Evaluation}

F80 series of citrumelos. Field trials and some commercial plantings of these citrumelos indicate that certain ones deserve additional evaluation. The citrumelos in this series do not differ greatly, but there are some measurable contrasts in tree size and yield among orange and grapefruit trees across these rootstocks. A comprehensive trial using citrumelo rootstocks was reported in the 1995 Proceedings of the Florida State Horticultural Society.

Recommended for small scale trial are: 80-7, particularly for somewhat smaller sized trees; and, 80-9, 80-14, and 80-18, which have performed well with Valencia scions in Gulf Coast and Indian River region trials, and with Marsh grapefruit in an Indian River trial (Fig. 1). These citrumelos are similar to Swingle in their horticultural characteristics. The most important unknown is their tolerance to decline conditions. In an Indian River trial, Marsh grapefruit trees on Swingle in Riviera soil declined and were removed when they were about 10 years old. No decline was observed among trees growing on other 
citrumelos in the trial until two years afterward, but that may have been the result of site conditions. More broadly based grower evaluation is needed.

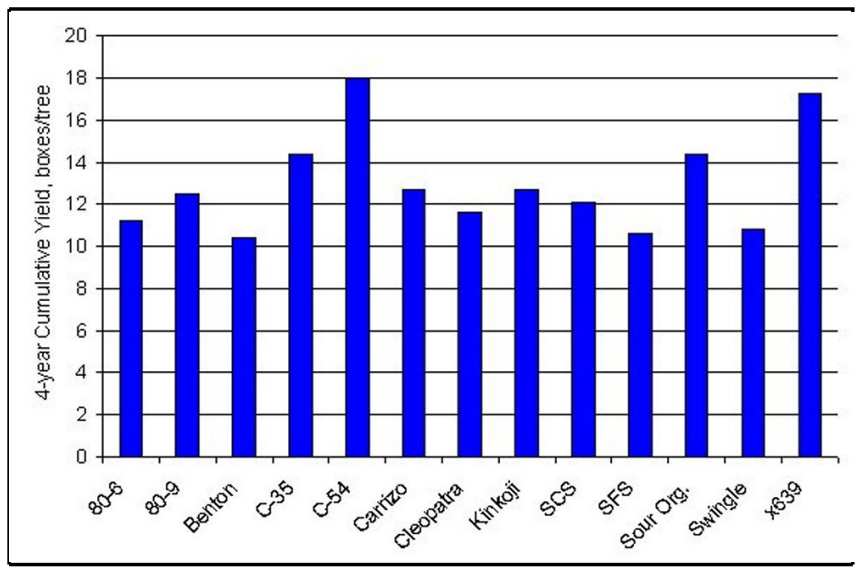

Figure 1. Cumulative yield of Marsh grapefruit trees planted near Hobe Sound in 1995 at $12 \mathrm{ft}$ x $22.5 \mathrm{ft}$. The rootstocks are citrumelos F80-6 and 80-9; Benton, C-35 and Carrizo citranges; C-54 mandarin hybrid, Cleopatra mandarin, Kinkoji, SCS-Sun Chu Sha mandarin, SFS-Smooth Flat Seville, sour orange, Swingle citrumelo, x639 hybrid.

\section{x639 Cleopatra mandarin-trifoliate orange}

hybrid. The data from field trials continues to support use of this rootstock (Fig. 1). Traits as listed in the Florida Citrus Rootstock Selection Guide, are still correct. The most important ones can be summarized as follows: x639 appears to behave like Cleo regarding blight: trees are susceptible but trees in the oldest trial planted in 1986 did not begin to decline until they were about 12 years old; soil adaptability is good and trees are growing well in Chobee, Riviera, and Winder soil types; fruit yield is comparatively good among navel, grapefruit, and sweet orange trees; fruit size is small with grapefruit and excellent with navels.

Kuharske citrange. The limited data available so far show that this rootstock, which originated in the Bay Lake, Florida nursery of Mac Kuharske, has good potential especially for oranges on the Ridge. It has excellent tolerance to the burrowing nematode, but otherwise is just like Carrizo, except its tolerance to blight has not been determined. Earlygold trees have grown and yielded well on this rootstock (see more in Earlying-Maturing Sweet Oranges: Research Update on Earlygold, Itaborai, Ruby, and Westin Sweet Oranges at http://edis.ifas.ufl.edu/HS173).
C-32 citrange. This rootstock is a C-35 sibling and seems to be a typical citrange, but the trees in various trials have been quite consistent in their vigor, large size, and excellent yield (Fig. 2). Blight tolerance is unknown. C-32 fruit are not as seedy as Carrizo. There would appear to be little risk, except possibly for blight, in using this rootstock for oranges or grapefruit.

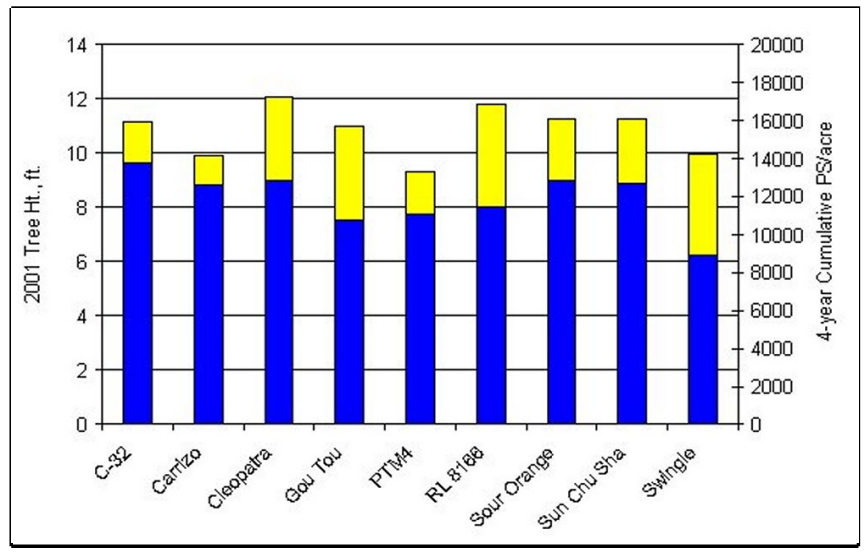

Figure 2. Tree height (yellow portion of each bar) and pounds-solids (PS) production (blue portion) of Valencia sweet orange trees planted south of Fort Pierce in 1990 at $12 \mathrm{ft}$. $25 \mathrm{ft}$. See Fig. 1 for rootstock abbreviations, also C-32 citrange, PTM4-trifoliate orange $\times$ Milam, and RL-rough lemon.

C-35 citrange. Trees on this rootstock are medium sized and productive. In Indian River trials, 8- to 10-year old grapefruit trees have been particularly impressive especially regarding fruit size and shape (Fig. 1). On the Ridge, both Hamlin and Earlygold trees are smaller than those on Swingle and have yielded well ((see more in Earlying-Maturing Sweet Oranges: Research Update on Earlygold, Itaborai, Ruby, and Westin Sweet Oranges at http://edis.ifas.ufl.edu/HS173). This rootstock might be an excellent choice to diminish the vigor of Minneola tangelo and improve its yield.

Sun Chu Sha mandarin (SCS). This rootstock was released because it was thought to have good tolerance to calcareous soils and blight. It has had a modest impact in our industry and is widely considered as just another Cleo. That opinion is probably justified using data from both commercial plantings and research trials. However, there have been some surprises and some distinctive traits have been observed. 
In a trial of Fallglo, Sunburst, and several unreleased mandarin types on eight rootstocks at the Water Conserv II site near Winter Garden. The trees on SCS were comparable to those on Cleo, but often slightly less vigorous and better yielding. Sun Chu Sha is a suitable rootstock choice for calcareous and clay soils, for places unsuited to Swingle, and for Hamlin and Murcott. Cleo and other mandarin rootstocks are questionable choices for nucellar Valencia budlines; however, in Valencia sweet orange and Marsh grapefruit Indian River trials, trees on SCS were among the top performers. In a Gulf Coast Valencia planting with whole beds of trees planted in 1991 on Malabar and Holopaw soils, 30\% of the trees on Cleo have gone out to blight with virtually no trees lost on SCS. Yield has been about 4 to 6 boxes/tree in recent years on SCS and 3 boxes for the trees on Swingle. The SCS yields were exceeded only by those of the trees on rough lemon.

PTM4 Trifoliate orange $x$ Milam. This hybrid was produced by Harry Ford (Lake Alfred Citrus Research and Education Center, retired) and has proven to be tolerant of both citrus and burrowing nematodes. It would appear to be an unlikely candidate for success at locations off the Ridge because neither parent has an established reputation in flatwoods areas. Nevertheless, it was included in a series of flatwoods trials where trees have displayed vigor similar to ones on Swingle, but are more productive (Fig. 2). Consistent and comparatively good yield is a feature of trees on PTM4 in a Hamlin trial planted in 1991, and a Marsh trial planted in 1990 on Pineda sand soil.

Murcott. Isn't this a scion variety? Yes, but it is also an interesting rootstock as demonstrated in several trials with lemon, sweet orange, and grapefruit varieties. Murcott fruit produce plenty of seed and uniform seedling populations, making it an excellent nursery plant. Scions budded to Murcott have excellent juice quality, good yield, and grow to standard tree size. In some small commercial plantings, Murcott trees on Murcott rootstock were less alternate bearing than ones on other rootstocks. Small trials with Murcott should be conducted in Swingle decline sites.

\section{UF/IFAS/Citrus Research and Education} Center (CREC), Lake Alfred. Plant improvement team is regularly producing new rootstock candidates, most of which are in the early stages of evaluation. However, propagation materials are available for some selections of sexual and somatic hybrids (produced by cell fusion, thereby containing all the genetic material of both parents as opposed to conventional breeding producing sexual hybrids containing $1 / 2$ of the genetic material of each parent). Growers interested and willing to participate in field trials are invited to contact Bill Castle, Jude Grosser, and Fred Gmitter directly. You can help us find answers to the "always-challenging question."

The USDA-Agricultural Research Service, Ft. Pierce. See Dr. Kim Bowman's web site (http://www.ushrl.saa.ars.usda.gov/hb/index.html) for descriptions of several promising rootstocks, including several mandarin hybrids, two of which have already been released as well as an extensive list of field trials with growers.

\section{On-Farm Evaluation}

After the preliminary work is complete and a new rootstock is ready for field trials, it then takes about 10 years to establish a trial and gather data. Additional study can easily add another 10 years before the rootstock is ready for release to growers. That's a long time to wait, so the process can be accelerated by involving cooperators as early as possible in the process.

Grower cooperation has two indisputable benefits: accelerated evaluation over a broader range of situations, and firsthand experience for the cooperator on his or her property. On-site evaluations are independent of the size of your operation. If you have 20 acres planted at 145 trees/acre, that's 2,900 trees. You could easily plant 10 trees each of three new rootstocks (which is 30 trees and only about $1 \%$ of the total), and likewise, for someone with 2,000 acres who sets aside $1 \%$ of the space for experimental purposes. There is virtually nothing to lose. If there are any extra costs, they are minimal and the trees will pay their way like any normal grove tree. You can simply observe the trees to form impressions, or data can be collected. Any grower can have the best 
of both worlds by keeping abreast of research results while learning at the same time from personal on-site study. There is really no reason why every grower shouldn't enjoy the full benefits of firsthand experience. It is one of the best mutually beneficial opportunities available in the industry today. Talk to your nursery tree supplier today!

\section{References}

Castle, W.S., and J.J. Ferguson. 2003.

Early-maturing sweet oranges: research update on Earlygold, Itaborai, Ruby, and Westin sweet oranges. HS920, Univ. of Fla., IFAS, Fla. Coop. Ext. Ser., (edis.ifas.ufl.edu/HS173)

Castle, W.S., and J.J. Ferguson. 2003b.

Considerations for choosing the right rootstocks. Univ. of Fla., IFAS, Fla. Coop. Ext. Ser., (edis.ifas.ufl.edu/HS178)

Castle, B., M. Bauer, B. Boman and T. Obreza. 2002. Some practical matters related to Riviera soil, depth to clay, water table, soil organic matter, and Swingle citrumelo root systems. HS894, Univ. of Fla., IFAS, Fla. Coop. Ext. Ser., (edis.ifas.ufl.edu/HS146)

Castle, W.S., D.P.H. Tucker. 1998. Florida citrus rootstock selection guide. SP248, Univ. of Fla., IFAS, Fla. Coop. Ext. Ser.

Youtsey, C.O. and O. Lee. 1995. A 6-year comparison between 16 rootstocks budded with 'Hamlin' sweet orange. Fla. State Hort. Soc. Proc. 58:69-73. 